\title{
Hybrid Microwave Treatment of SRS TRU and Mixed Wastes
}

by

G. G. Wicks

Westinghouse Savannah River Company

Savannah River Site

Aiken, South Carolina 29808

R. L. Schulz

This paper was prepared in connection with work done under the above contract number with the U. S. Department of Energy. By acceptance of this paper, the publisher and/or recipient acknowledges the U.S. Government's right to retain a nonexclusive, royalty-free license in and to any copyright covering this paper, along with the right to reproduce and to authorize others to reproduce all or part of the copyrighted paper. 


\section{DISCLAIMER}

This report was prepared as an account of work sponsored by an agency of the United States Government. Neither the United States Government nor any agency thereof, nor any of their employees, makes any warranty, express or implied, or assumes any legal liability or responsibility for the accuracy, completeness, or usefulness of any information, apparatus, product or process disclosed, or represents that its use would not infringe privately owned rights. Reference herein to any specific commercial product, process or service by trade name, trademark, manufacturer, or otherwise does not necessarily constitute or imply its endorsement, recommendation, or favoring by the United States Government or any agency thereof. The views and opinions of authors expressed herein do not necessarily state or reflect those of the United States Government or any agency thereof.

This report has been reproduced directly from the best available copy.

Available for sale to the public, in paper, from: U.S. Department of Commerce, National Technical Information Service, 5285 Port Royal Road, Springfield, VA 22161

phone: (800) 553-6847

fax: (703) 605-6900

email: orders@ntis.fedworld.gov

online ordering: http://www.ntis.gov/ordering.htm

Available electronically at http://www.doe.gov/bridge

Available for a processing fee to U.S. Department of Energy and its contractors, in paper, from: U.S. Department of Energy, Office of Scientific and Technical Information, P.O. Box 62, Oak Ridge, TN 37831-0062

phone: (865)576-8401

fax: (865)576-5728

email: reports@adonis.osti.gov 


\section{DISCLAIMER}

Portions of this document may be illegible in electronic image products. Images are produced from the best available original document. 
October 21, 1999

Key Words: TRU Waste, Mixed Waste, Microwave

TO:

$$
\begin{aligned}
& \text { Frank Utsch (773-41A) } \\
& \text { Bill Holtzscheiter (773A) } \\
& \text { Ed Stevens (773A) } \\
& \text { John Veldman (773A) } \\
& \text { Dale Ormond (703A) }
\end{aligned}
$$

Peter Hudson (705-3C)

Brent Daugherty (705-3C)

Vinod Bhambri (705-3C)

Joe D'Amelio (724-35E)

Jim Blandenhorn (724-35E)

FROM: $\quad$ Rebecca Schulz* (5-7387) and George Wicks (5-3190)

HYBRID MICROWAVE TREATMENT Of SRS TRU \& MIXED WASTES (U) FINAL REPORT for Strategic R\&D Program

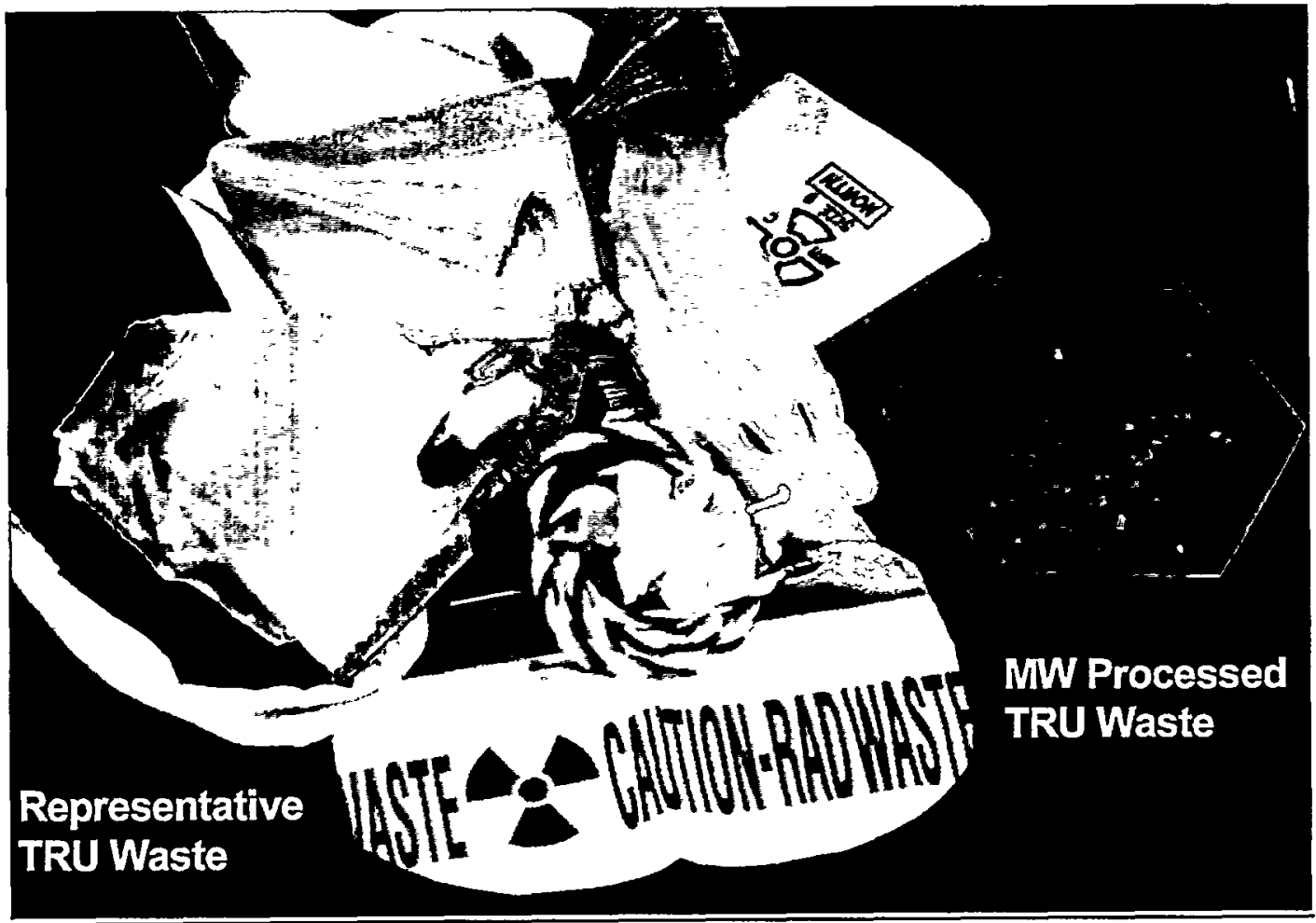

\section{EXECUTIVE SUMMARY}

A new process, using hybrid microwave energy, has been developed as part of the Strategic R\&D program and successfully applied to treatment of a wide variety of non- 
radioactive materials, representative of SRS transuranic (TRU) and mixed wastes. Over 35 simulated (non-radioactive) TRU \& mixed waste materials were processed individually, as well as in mixed batches, using hybrid microwave energy, a new technology now being patented by WSRC. These materials were also successfully processed in a "bag-in-bag" configuration, without removing the wastes from their containment bags. The materials used in this study included anti-C coveralls, pylox gloves, rope, cotton mop heads, filters, tritium suit, yellow tarp, masking tape, HDPE sample bottles, $1000 \mathrm{ml}$ bottles, tissue paper, utility cloth, treated wood, PVC air hose, tygon tubing, duct tape, laundry bag \& tarp, absorbent pad, hand towels, protective coveralls, corrugated boxes, Neoprene/ Hycar face shield, cotton gloves, Nylon, rubber \& cloth shoe covers, MSA combination cartridge, brown paper, organic vapor cartridge, anti-C gloves, etc. All samples and mixes studied were treated successfully, significantly reducing the original organic content and a main source of gas generation, which could adversely effect shipping of TRU containers to the Waste Isolation Pilot Plant (WIPP). In this process, significant waste volume reductions typically in the $60-90 \%$ range, were also achieved.

As part of this effort and building upon the successfully Strategic R\&D laboratory work involving non-radioactive TRU and mixed wastes, a proposal was issued detailing a oneyear program to demonstrate this technology using actual or radioactive TRU materials at SRS. The proposed "hot" demonstration project could be conducted for total estimated cost of $\$ 779 \mathrm{~K}$ and based on calculations of cost savings and returns of investment, has the potential of realizing more than 3 million dollars in cost savings, if the technology proves successful and is implemented in the plant. Among the main advantages of remediating SRS TRU wastes using this hybrid microwave operation are a) elimination of organic constituents in the waste (main source of gas generation), b) significant waste volume reductions, c) improved safety in storage, transportation and disposal and d) overall cost savings.

\section{BACKGROUND OF PROBLEM}

A waste management need exists at the Savannah River Site (SRS) to effectively treat a large volume of TRU waste materials. TRU waste is comprised of a wide variety of items such as paper, polymer and glassware products, wood and metals as well as small equipment. Of particular interest and importance is the organic content of the waste. The organics not only occupy a relatively large volume of the total waste content, but hydrogen gas is produced as a result of alpha radiolysis of the organic materials. This results in a potentially explosive mixture of hydrogen and oxygen and prevents shipment to WIPP for disposal. Destruction of organic materials reduces the potential for generating hydrogen and increases the allowable isotopic loading within the transportation container. Furthermore, individuals and groups such as the SRS Citizens Advisory Board have recommended thermal destruction of SRS TRU waste as a treatment option. If a treatment option is not selected, this could result in permanent storage of at least some of the waste at SRS, which would have undesirable consequences. This would include additional storage costs, increased risk of not meeting regulatory requirements and increased ES\&H risks to SRS personnel, the public and the environment.

There are many advantages of treating this waste using a new and exciting technology called Hybrid Microwave Treatment. It involves little or no pre-treatment of the waste and is flexible enough to handle a wide range of waste materials without extensive or elaborate changes in equipment design. The technology can also be readily retrofitted to existing $\mathrm{Pu}$ facilities and handling capabilities. This treatment concept is also especially 
suited to remote operations, since the electronics and microwave generating devices can be located in a different area than the microwave treatment cavity, which can be used in a contained or remote workspace. This enables easy maintenance, if needed, in both a time and cost effective manner and more importantly, minimizes the potential exposure to operating personnel, consistent with site ALARA principles.

\section{HYBRID MICROWAVE TECHNOLOGY}

Microwave energy represents a heating source that is unique compared to all other electrical or thermal processes. Energy is able to penetrate a material and heat it from the inside out, thus making the heating process both effective and flexible. This energy has already been used successfully in treatment of a wide variety of wastes, and temperatures can be achieved to not only destroy organic components but to vitrify wastes, if desired. The economic benefits of using this type of energy source for vitrification of radioactive wastes, compared to other more conventional sources, has recently been assessed and documented by Lawrence Livermore National Laboratory (LLNL).

Researchers from SRTC and the University of Florida (UF) have developed an improved heating concept using hybrid microwave energy and applied this treatment to a variety of liquid, solid and gaseous waste streams $(1,2)$. Their efforts using "Hybrid Microwave Treatments," were highlighted recently in C\&E News as well as in many technical papers. During the development process, a system was constructed to handle not only primary wastes, but also the secondary wastes or off-gases that were produced. The team has applied this technology on a laboratory scale to disposition of electronic circuitry and reclamation of the precious metals within, to treatment of used rubber tires for recycling, medical wastes, weapons components, and to simulated HLW, TRU and mixed waste streams.

The versatility of using microwave energy to remediate various wastes has been demonstrated in many national and international laboratories (3). For example, international researchers have successfully treated high-level radioactive waste using microwaves and in Japan, microwave energy in conjunction with conventional techniques, is being used to vitrify plutonium-bearing materials. Microwave energy offers the potential to successfully treat a wide range of waste types and as demonstrated, simulated SRS TRU and mixed waste compositions. Microwave processing significantly reduces the volume of TRU wastes, destroys organic components, reduces off-gases produced, and if desired, can also vitrify the remaining residue into a safe wasteform suitable for storage, transportation or ultimate disposal at WIPP. In Figure 1, the SRTC "tandem" hybrid microwave system is shown which treats not only the primary wastes, but also secondary wastes or off-gases produced. Technical publications and presentations, giving more details on studies and results produced using this technology, are provided in references (4-17). 


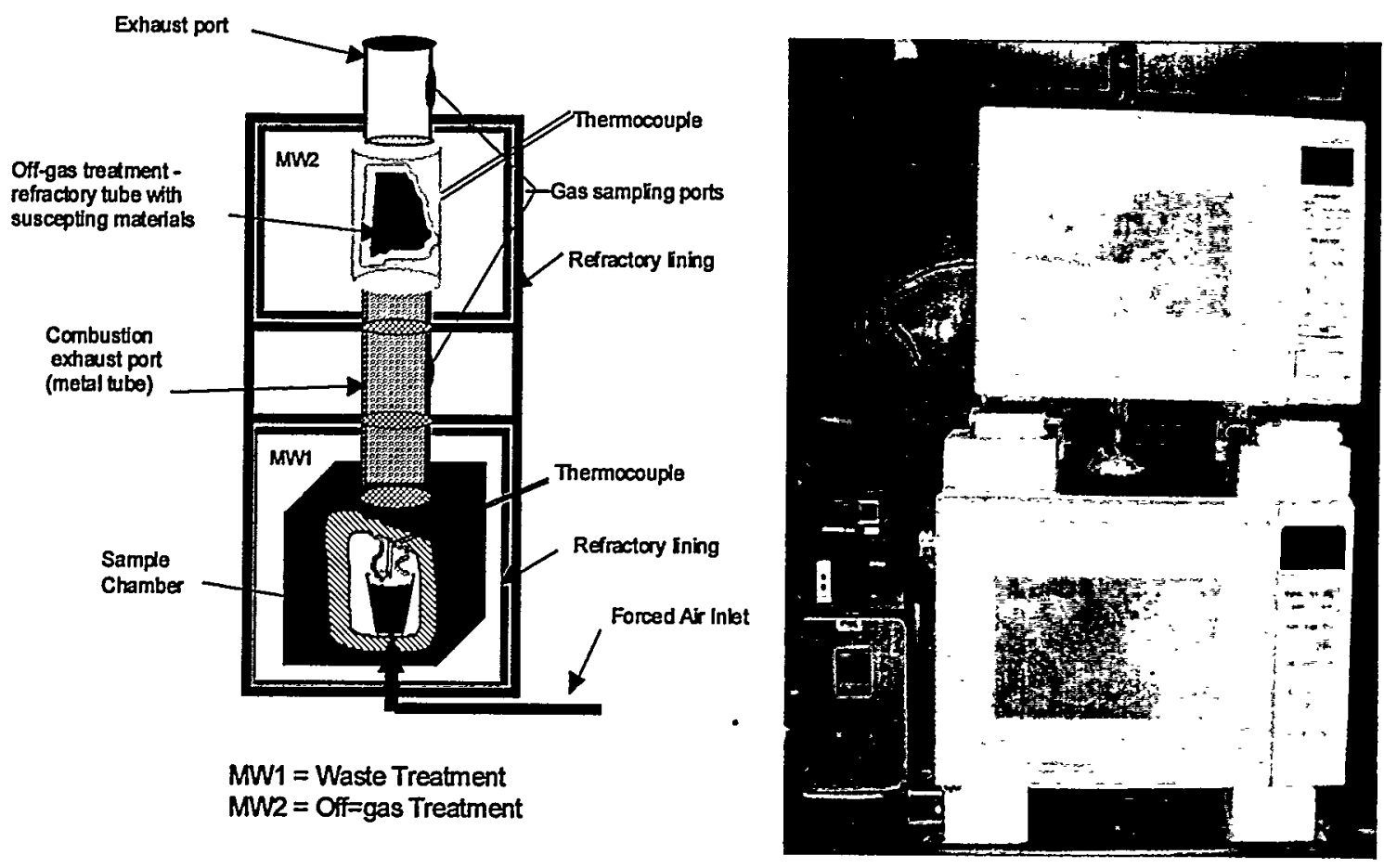

Figure 1 SRTC Tandem Microwave System

\section{EXPERIMENTAL PROGRAM}

\section{Laboratory Tests on Hybrid Microwave Treatment of Simulated SRS TRU Wastes}

As part of the Strategic R\&D Program, hybrid microwave technology was assessed for remediation of simulated SRS TRU and mixed wastes. Over 35 different waste types were studied and evaluated. These waste materials were in the form of shredded material and whole items or large pieces. The materials were subjected to microwave processing individually and in mixed batches. Simulated TRU and mixed wastes evaluated in the present study include the following:

Shredded TRU Waste Materials

Anti-C Coveralls

Tritium Suit

HDPE Sample Bottle

Treated Wood

Yellow Shoecover

Absorbent Pad

Rad Bags

Caution Tape

Pylox Glove
Cotton Mop Head

Yellow Tarp

Tissue Paper

PVC Air Hose

Duct Tape

Hand Towels

$1000 \mathrm{ml}$ Bottle

Corregated Box

Cotton Gloves
Filter

Masking Tape

Utility Cloth

Tygon Tubing

Laundry Bag/Tarp

Protective Coverall

Neoprene Rubber Overshoe

Y/M Rope

Flame Resistant Paper

Neoprene/Hycar Full Face Shield MSA Combination Cartridge Draeger Organic Vapor Cartridge 
Mixed Batch Tests (Shredded Material)

STRW-1 (Anti-C coverall, tritium suit, treated wood,HDPE sample bottle, yellow shoecover, absorbent pad, Neoprene rubber shoecover)

STRW-2 (Cotton mop head, yellow tarp, white tissue paper, PVC air hose, duct tape)

STRW-3 (Paper hand towel, rad bag, "Caution Rad. Matl" tape, Pylox glove, corrugated box, flame resistant paper)

STRW-4 (10 $\mu$ filter paper, launderable bag, rad waste bag, masking tape, utility cloth, Tygon plastic tubing)

STRW-5 (Protective coverall, surgical glove, $1000 \mathrm{ml}$ sample bottle, yellow/magenta Nylon rope, cotton gloves)

Mixed Batch Tests (Whole Items or Large Pieces)

WTRW-1 (MSA combination cartridge pieces, MSA Neoprene/Hycar face shield pieces, Nylon/rubber shoecover, corrugated rad waste box, cloth bootie)

WTRW-2 (Draeger organic vapor cartridge pieces, silicone face shield, Northon anti-C glove, absorbent pad)

WTRW-3 (MSA chemical cartridge pieces, MSA Mersorb indicator cartridge pieces,yellow coveralls, flame resistant paper, cotton glove)

WTRW-4 (Flame resistant paper, masking tape, blue kimwipe, rad waste bag,

WTRW-5 MSA combination cartridge pieces, silicon face shield, yellow/magenta

WTRW-6 Nylon rope, paper towel, Neoprene full face mask pieces, anti-C

WTRW-7 rubber gloves, DOE coveralls)

Most of the tests conducted were on mixed batches. In Figure 2, photographs depicting TRU waste materials before and after microwave processing are shown. All of the mixed batches were successfully treated with microwave energy and all produced an ash (or could be vitrified with addition of glass additives), and all resulted in significant volume reductions.
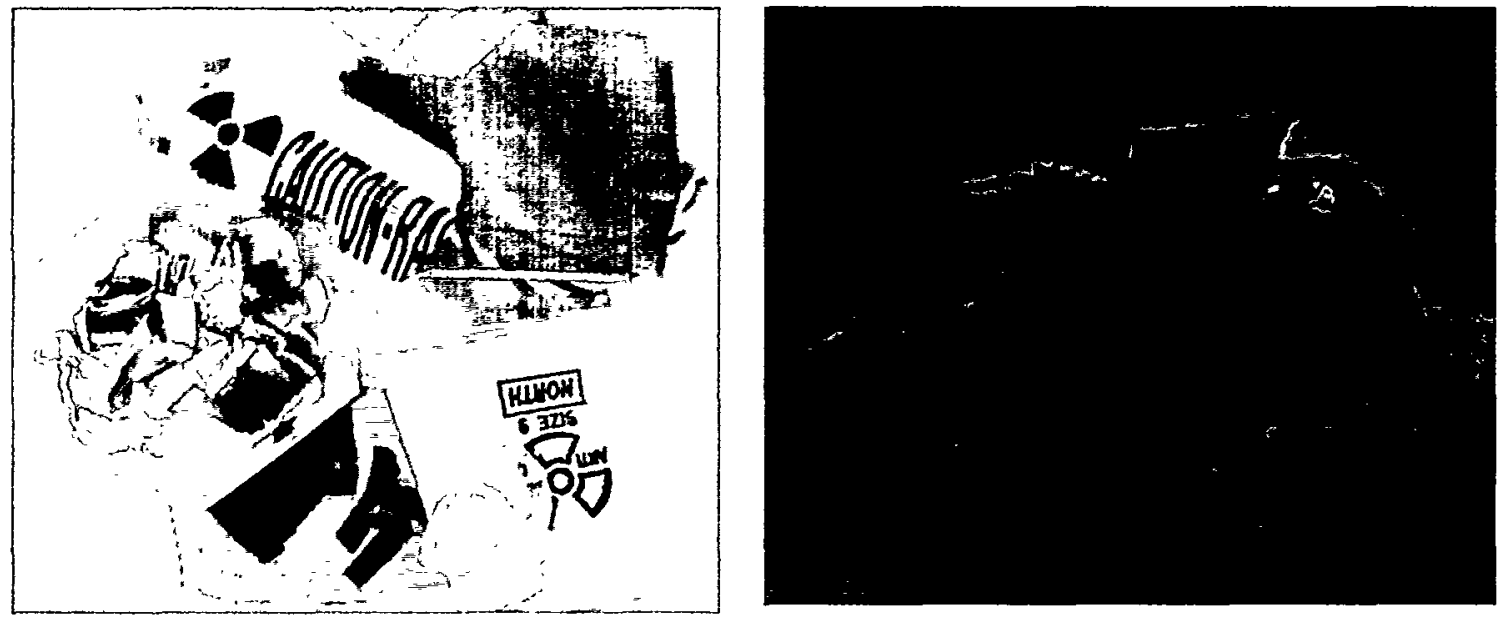

Figure 2 TRU Waste Mixes Before and After Processing (1044 ${ }^{\circ} \mathrm{C}$ for $\left.105 \mathrm{~min}.\right)$

Waste was also successfully treated while still inside containment bags. The bag-in-bag configurations containing TRU mixes were placed directly into the microwave system 
and destroyed, without removing the waste from the bags. The before and after photographs for these tests are shown in Figure 3.

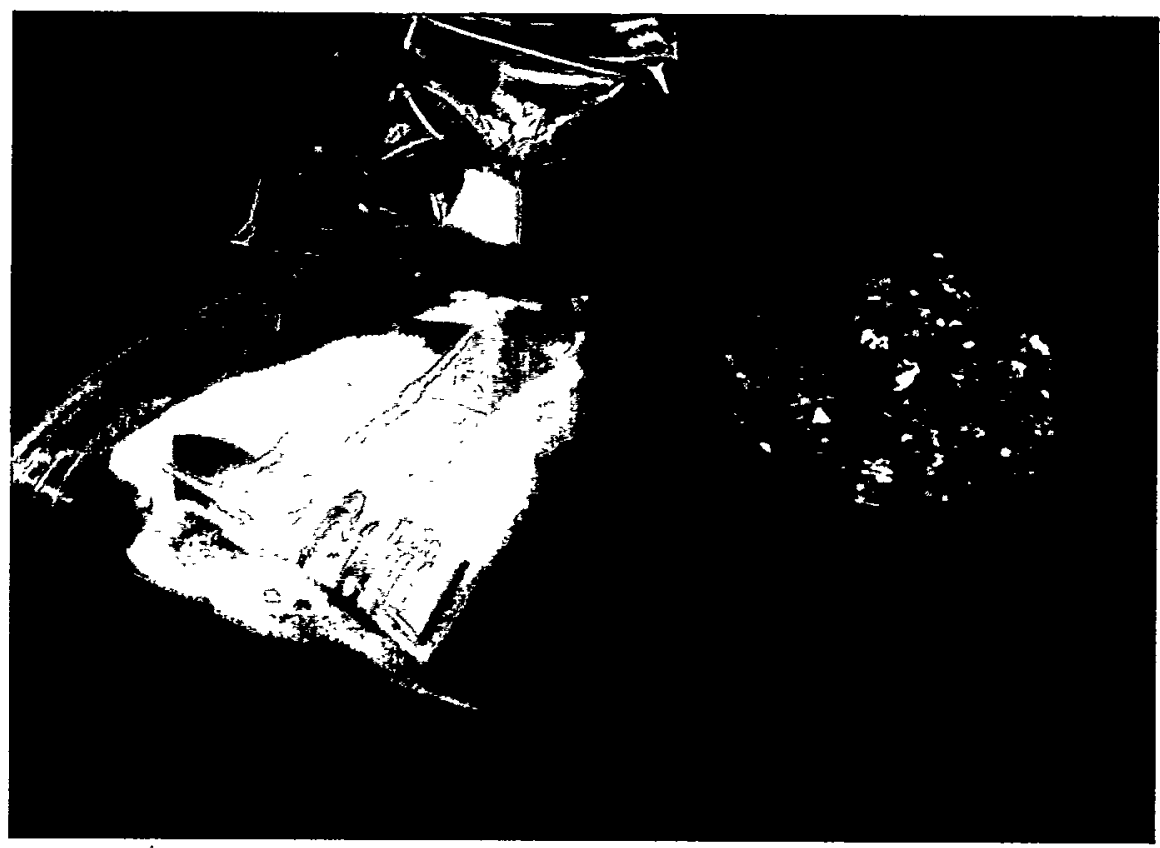

Figure 3 "Bag-in-bag" non-radioactive TRU waste before and after processing (Temperature: $1075^{\circ} \mathrm{C}$, time: 45 min., wt. Reduction: $83.4 \%$, vol. Reduction: $87.5 \%$ )

In Figures 4 and 5, corresponding weight and volume reductions, along with testing conditions for microwave processing of various TRU and mixed waste mixtures, are summarized graphically. All of the treated non-radioactive TRU and mixed wastes were treated successfully, both individually and in a variety of different mixed batches. As noted in the figures, volume reductions resulting from microwave processing are significant and typically in the $60-90 \%$ range. In addition to treatment of these materials, the off-gases produced were also successfully treated using this new technology and the tandem microwave unit.

There were four main classes of non-radioactive TRU and mixed waste evaluated in the off-gas study. These samples involved mixes of a) plastics (TW-Plastic), b) paper (TWPaper), c) cloth (TW-Cloth) and e) heterogeneous mixes of diverse materials (TWMixed) and are given as follows:

TW-Plastic

TW-Paper

TW-Cloth

TW- Mixed
(Rad waste bag, shoe covers, face shield, rubber gloves)

(Flame resistant paper, paper towels, corregated box)

(Coveralls, shoe covers, Handi-wipes, glove liners)

(Flame resistant paper, rad waste bg, Handi-wipes, rubber gloves, yellow/ Magenta rope, face shield pieces, coveralls) 


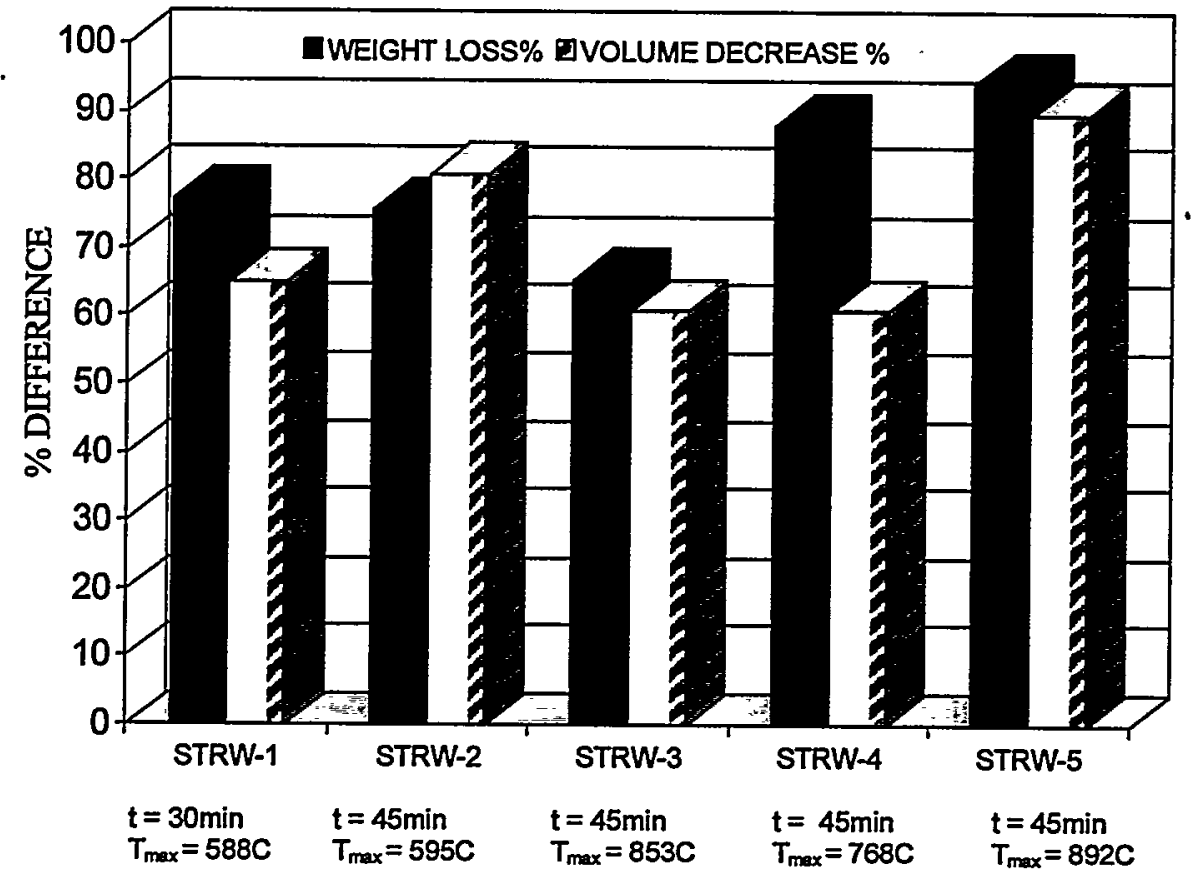

Figure 4. Shredded TRU Waste Weight and Volume Reductions

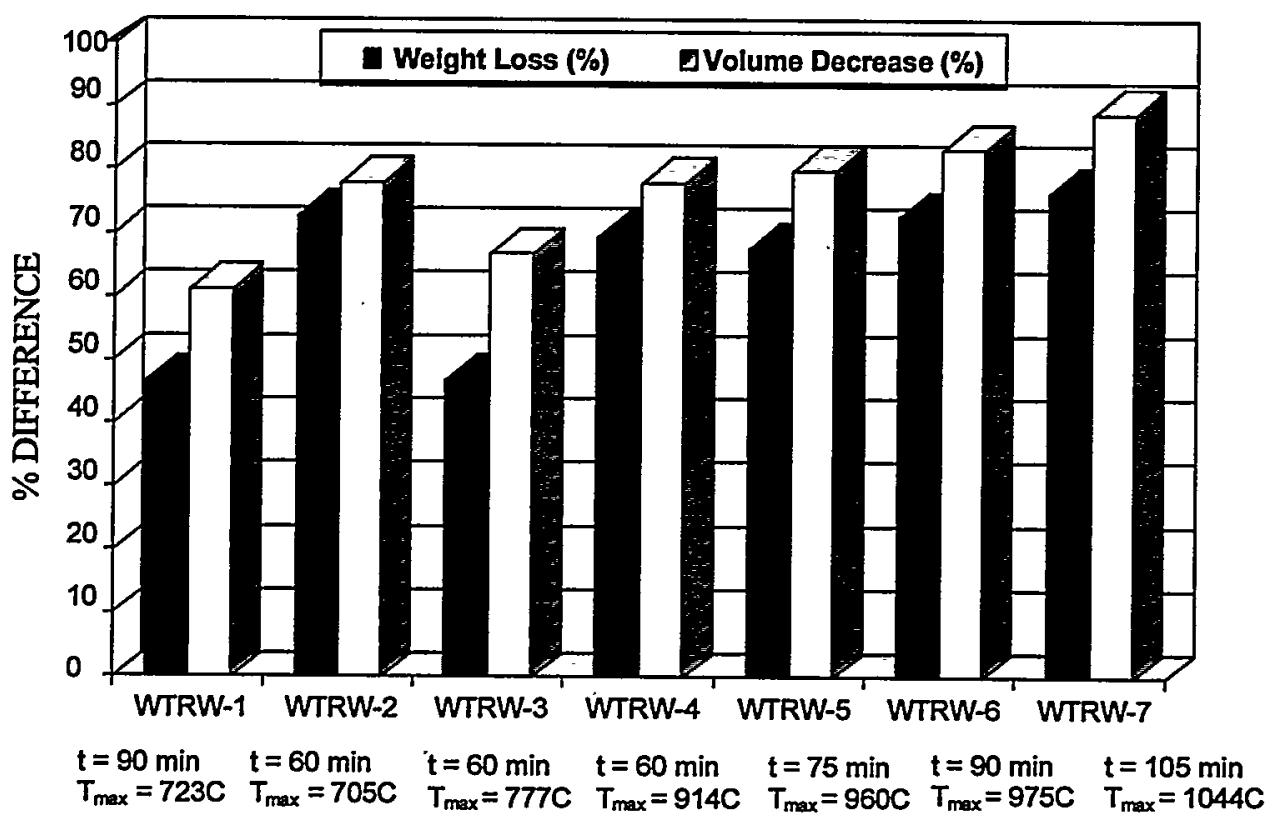

Figure 5. Whole TRU Waste Weight and Volume Reductions 
Over 40 chemical species were assessed in the off-gas stream after microwaving each of these various classes of non-radioactive TRU and mixed wastes. The tests not only evaluated each of the classes separately, but also mixed wastes in a bag-in-bag configuration. In almost all cases, the species measured (to be released) were below detection limits, after being treated by the microwave off-gas system. For the "TWPaper" mix, species measured in the off-gases were below detection limits both before and after microwave treatment. However, the effects of the microwave off-gas remediation system were readily apparent from the data produced from treating the "TWPlastic," "TW-Cloth" and "TW-Mixed" mixtures. In some cases, improvements of 3 orders of magnitude were observed. Further improvements in efficiency seem likely by simply increasing the residence time for treatment. In Table 1, Gas ChromatographyMass Spectroscopy results are summarized, before and after microwave treatment for more than $\mathbf{4 0}$ different chemical species.

Table 1 Gas Chromatography- Mass Spectroscopy Results

\begin{tabular}{|c|c|c|c|c|c|c|}
\hline \multirow[t]{2}{*}{ Compound } & \multicolumn{2}{|c|}{$\begin{array}{l}\text { TW-Plastic } \\
\text { Conc. }(\mu \mathrm{g} / \text { tube })\end{array}$} & \multicolumn{2}{|c|}{$\begin{array}{c}\text { TW-Cloth } \\
\text { Conc. }(\mu \mathrm{g} / \text { tube })\end{array}$} & \multicolumn{2}{|c|}{$\begin{array}{c}\text { TW-Mixed } \\
\text { Conc. }(\mu \mathrm{g} / \text { tube })\end{array}$} \\
\hline & & After & Befor & After & Before & After \\
\hline Acetophenone & Nd & $\mathrm{Nd**}$ & $\mathrm{Nd}$ & Nd & 171 & Nd \\
\hline Limonene & 2742 & Nd & Nd & Nd & 218 & $\mathrm{Nd}$ \\
\hline Phenol $^{*}$ & 967 & Nd & $\mathrm{Nd}$ & Nd & 2003 & $\mathrm{Nd}$ \\
\hline Phenol, 2-(Imethylethyl) & 144 & $\mathrm{Nd}$ & $\mathrm{Nd}$ & $\mathrm{Nd}$ & Nd & Nd \\
\hline Phenol, 4-(Imethylethyl) & 117 & Nd & Nd & Nd & 776 & $\mathrm{Nd}$ \\
\hline Phenol, 2-ethyl & $\mathrm{Nd}$ & $\mathrm{Nd}$ & $\mathrm{Nd}$ & Nd & 59 & $\mathrm{Nd}$ \\
\hline Phenol, 4-ethyl & 68 & $\mathrm{Nd}$ & $\mathrm{Nd}$ & $\mathrm{Nd}$ & 360 & $\mathrm{Nd}$ \\
\hline Phenol, 2-methyl & $\mathrm{Nd}$ & Nd & Nd & Nd & 63 & $\mathrm{Nd}$ \\
\hline Phenol, 4-methyl & $\mathrm{Nd}$ & $\mathrm{Nd}$ & $\mathrm{Nd}$ & Nd & 1029 & $\mathrm{Nd}$ \\
\hline p-Xylene* & 239 & $\mathrm{Nd}$ & Nd & Nd & 1306 & $\mathrm{Nd}$ \\
\hline Ethanol, 2-butoxy- & 109 & $\mathrm{Nd}$ & Nd & Nd & $\mathrm{Na}$ & $\mathrm{Nd}$ \\
\hline 1,3 Cyclohexadien & 106 & $\mathrm{Nd}$ & $\mathrm{Nd}$ & $\mathrm{Nd}$ & Nd & $\mathrm{Nd}$ \\
\hline $\begin{array}{l}\text { Cyclohexane } \\
\text { 1,1-dimethyl-2-propyl }\end{array}$ & Nd & $\mathrm{Nd}$ & $\mathrm{Nd}$ & $\mathrm{Nd}$ & 87 & Nd \\
\hline $\begin{array}{l}\text { Cyclohexane, } \\
1,2,4 \text {-trimethyl }\end{array}$ & Nd & $\mathrm{Nd}$ & $\mathrm{Nd}$ & $\mathrm{Nd}$ & 79 & $\mathrm{Nd}$ \\
\hline Cyclododecane & $\mathrm{Nd}$ & Nd & $\mathrm{Nd}$ & Nd & 76 & $\mathrm{Nd}$ \\
\hline Styrene ${ }^{*}$ & 91 & $\mathrm{Nd}$ & Nd & $\mathrm{Nd}$ & $\mathrm{Nd}$ & Nd \\
\hline $\begin{array}{l}\text { Cyclotetrasiloxane, } \\
\text { octamethyl }\end{array}$ & 254 & $\mathrm{Nd}$ & $\mathrm{Nd}$ & $\mathrm{Nd}$ & Nd & Nd \\
\hline Benzene, 1-ethyl-2-methyI & 57 & Nd & Nd & Nd & $\mathrm{Nd}$ & $\mathrm{Nd}$ \\
\hline Benzene, 1,2 -dimethyl & Nd & Nd & Nd & Nd & 329 & Nd \\
\hline Benzene 1-ethyl-2-methyl & Nd & $\mathrm{Nd}$ & Nd & Nd & 197 & $\mathrm{Nd}$ \\
\hline $\begin{array}{l}\text { Benzene, } \\
\text { 1-methyl-4-(1methylethen) }\end{array}$ & $\mathrm{Nd}$ & Nd & Nd & Nd & Nd & Nd \\
\hline $\begin{array}{l}\text { Benzene, } \\
\text { methyl(1methylethel) }\end{array}$ & Nd & $\mathrm{Nd}$ & $\mathrm{Nd}$ & $\mathrm{Nd}$ & $\mathrm{Nd}$ & 430 \\
\hline $\begin{array}{l}\text { Benzene, } \\
\text { 1-ethyl-3-5-dimethyl }\end{array}$ & $\mathrm{Nd}$ & Nd & Nd & Nd & 53 & $\mathrm{Nd}$ \\
\hline Benzene isocyano- & $\mathrm{Nd}$ & $\mathrm{Nd}$ & $\mathrm{Nd}$ & $\mathrm{Nd}$ & $\mathrm{Nd}$ & 66 \\
\hline Benzonitrile & Nd & $\mathrm{Nd}$ & Nd & Nd & 492 & Nd \\
\hline
\end{tabular}


Table 1 Gas Chromatography- Mass Spectroscopy Results (Con't)

\begin{tabular}{|c|c|c|c|c|c|c|}
\hline \multirow[t]{2}{*}{ Compound } & \multicolumn{2}{|c|}{$\begin{array}{c}\text { TW-Plastic } \\
\text { Conc. }(\mu \mathrm{g} / \text { tube })\end{array}$} & \multicolumn{2}{|c|}{$\begin{array}{c}\text { TW-Cloth } \\
\text { Conc. ( } \mu \mathrm{g} / \text { tube) }\end{array}$} & \multicolumn{2}{|c|}{$\begin{array}{c}\text { TW-Mixed } \\
\text { Conc. }(\mu \mathrm{g} / \text { tube })\end{array}$} \\
\hline & Before & After & Before & After & Before & After \\
\hline Butane, 1-2-chloroethoxy & 66 & $\mathrm{Nd}^{* *}$ & $\mathrm{Nd}$ & $\mathrm{Nd}$ & 73 & Nd \\
\hline 1-Decene & 57 & $\mathrm{Nd}$ & $\mathrm{Na}$ & Nd & Nd & Nd \\
\hline Phenol, m-methyl & 50 & $\mathrm{Nd}$ & $\mathrm{Nd}$ & Nd & Nd & $\mathrm{Nd}$ \\
\hline $\begin{array}{l}\text { 2-Furancarboxaldehyde, } \\
\text { 5-methyl }\end{array}$ & Nd & Nd & Nd & Nd & $\mathrm{Nd}$ & Nd \\
\hline 3-Furanmethanol & $\mathrm{Na}$ & $\mathrm{Na}$ & $\mathrm{Nd}$ & Nd & 73 & $\mathrm{Nd}$ \\
\hline Furfural & $\mathrm{Nd}$ & Nd & 933 & $\mathrm{Nd}$ & $\mathrm{Na}$ & Nd \\
\hline Ethylbenzene* $^{*}$ & $\mathrm{Nd}$ & Nd & 177 & $\mathrm{Nd}$ & 179 & Nd \\
\hline Benzonitrile & $\mathrm{Nd}$ & Nd & 162 & $\mathrm{Nd}$ & Nd & $\mathrm{Nd}$ \\
\hline Acetophenone & $\mathrm{Nd}$ & $\mathrm{Nd}$ & TI1 & Nd & $\mathrm{Na}$ & Nd \\
\hline Benzoic acid, ethyl ester & Nd & Na & 54 & Nd & $\mathrm{Nd}$ & Nd \\
\hline D-Limonene & $\mathrm{Nd}$ & $\mathrm{Nd}$ & $\mathrm{Nd}$ & Nd & 3329 & $\mathrm{Nd}$ \\
\hline Indene & Nd & $\mathrm{Nd}$ & $\mathrm{Nd}$ & $\mathrm{Nd}$ & 112 & $\mathrm{Nd}$ \\
\hline IH-Indene, 1-methyl & $\mathrm{Nd}$ & Nd & $\mathrm{Nd}$ & $\mathrm{Nd}$ & 84 & $\mathrm{Nd}$ \\
\hline Hexadeconol & Nd & $\mathrm{Nd}$ & $\mathrm{Na}$ & Nd & 71 & $\mathrm{Nd}$ \\
\hline Pentadecene & Nd & $\mathrm{Nd}$ & Nd & $\mathrm{Nd}$ & 87 & Nd \\
\hline T-Trudecanol & $\mathrm{Nd}$ & $\mathrm{Nd}$ & $\mathrm{Nd}$ & $\mathrm{Nd}$ & 61 & $\mathrm{Nd}$ \\
\hline $\begin{array}{l}\text { 3-3,4Diethoxphenyl } \\
\text { propylamine }\end{array}$ & Nd & Nd & $\mathrm{Nd}$ & $\mathrm{Nd}$ & 89 & Nd \\
\hline Ethanol, 2-butoxy & $\mathrm{Nd}$ & $\mathrm{Nd}$ & $\mathrm{Nd}$ & $\mathrm{Nd}$ & 140 & $\mathrm{Nd}$ \\
\hline
\end{tabular}

* denotes Clean Air Hazardous Emission

** denotes Not Detected

\section{Results of Microwave Treatment of Simulated TRU/Mixed Wastes:}

- A tandem microwave system was utilized which simultaneously, treated primary wastes (TRU \& mixed wastes) as well as secondary wastes (emissions) that were produced.

- The "hybrid microwave" system successfully treated over 35 simulated TRU \& mixed waste materials individually, in mixed batches and in a bag-in-bag configuration.

- All samples and mixes studied to date were treated successfully. Also, off-gases analyzed and associated with the Clear Air Act were found to be below detection limits, after microwave processing.

- Volume reductions were typically in the $60-90 \%$ range and weight reductions in the $45-75 \%$ range for mixed batch treatments

- Improved control of the treatment process was also achieved by using a nitrogen atmosphere, which also allowed processing without producing flames.

- Over the past two years, the SRS patented hybrid microwave technology was highlighted in "Nuclear Waste News," "Waste Treatment Technology News" and "Hazardous Waste News," and three requests were received to have SRS personnel write review articles on this technology for other publications 


\section{Proposed "Hot Demonstration" on Actual TRU Wastes}

Based on the successes achieved in studies of simulated TRU and mixed wastes, a 'Hot Demonstration Project' was proposed to treat actual SRS TRU materials. The Demo is termed a "Hot Demo- Plus" because the objectives are not only to demonstrate the applicability of the hybrid microwave technology on actual radioactive materials, but to use this demo system to remediate some of the newly generated TRU waste inventory. The remediation proposal is designed to reduce waste volume, eliminate organic content of the materials and simultaneously treat off-gases and particles produced. The proposed demo is designed to operate for one year and treat over a hundred cubic feet of TRU waste, while assessing the effectiveness and efficiency of the new technology. This proposal is provided elsewhere (18).

\section{Potential Cost Savings}

The ability to remediate SRS TRU waste can result in significant cost savings through a) volume reductions and b) significantly reducing organic content of the waste which in turn, will alleviate gas generation problems and help facilitate ultimate shipping of TRU waste to WIPP. The following are rough calculations based on potential cost savings that can be realized due solely to reductions in TRU waste volume resulting from microwave processing of the waste. Operations and capital costs would need to be considered against savings. The assumptions for the calculations are given and are considered conservative. The actual cost savings realized could be considerably greater.

\section{Assumptions:}

1) Projected generated FY' 98 TRU inventory $17,668 \mathrm{ft}^{3}$

2) Waste Avoidance/ Pollution Prevention Costs $\$ 377 / \mathrm{ft}^{3}$ Cost for FY' 98 TRU Waste $\simeq 6.66 \mathrm{M}$

If one assumes a constant, conservative cost of $\$ 377 / \mathrm{cu}$. $\mathrm{ft}$. (which is less than half the new projected life cycle costs of $\$ 810 / \mathrm{cu}$. ft. for TRU wastes in 1999), the following is a rough estimate of cost savings on FY '98 inventory as a function of volume reduction:

\begin{tabular}{ccc} 
Vol. Reduction & Cost & Estimated Savings \\
\hline $50 \%$ & $3.330 \mathrm{M}$ & $\sim 3.3 \mathrm{M}$ \\
$60 \%$ & $2.664 \mathrm{M}$ & $\sim 4.0 \mathrm{M}$ \\
$70 \%$ & $1.998 \mathrm{M}$ & $\sim 4.7 \mathrm{M}$
\end{tabular}

Note: - Laboratory tests showed volume reductions generally in the $60-90 \%$ range

- Possible returns on investment via recycling and resale of $\mathrm{Pu}-238$ powder not considered in this analysis

- The $\$ 377 / \mathrm{cu}$. ft. potential cost savings figure was obtained from Solid Waste personnel as a first-cut, rough estimate of the savings resulting from volume reduction of SRS TRU waste

Processing Considerations:

The following are some processing considerations for treating a one-year (FY-'98) TRU inventory: 
- To process $17,668 \mathrm{ft}^{3}$ over one year (assuming 260 days $x .75$ utility $=195$ days), one must process about $90 \mathrm{ft}^{3}$ per day.

- For a moderately sized MW unit of 6400 watts, batches of approximately 8-10 $\mathrm{ft}^{3}$ could be processed in 1-2 hours per batch. At this rate, it would take about one shift (approximately 8-10 hours) to process $50 \mathrm{ft}^{3}$ per day or two units to produce 90-100 $\mathrm{ft}^{3}$ per day.

- Therefore, to work off the entire FY '98 inventory would require about one year using two moderately sized MW units

\section{CONCLUSIONS}

As discussed in the text, the remediation of SRS TRU and mixed wastes, using the SRS patented hybrid microwave process, has the potential of a) producing significant volume reductions, b) realizing large cost savings, c) improving safety considerations and d) facilitating the transportation and ultimate disposal of SRS TRU and mixed wastes.

\section{REFERENCES}

1 WSRC Flyer- "Hybrid Microwave Technology for Waste Management Applications", Westinghouse Savannah River Company/ University of Florida.

2 WSRC/ DOE Technology Brief: "Using Microwaves to Recover Important Metals from Electronic Circuitry.

3 "EPA Handbook: Vitrification Technologies for Treatment of Hazardous and Radioactive Waste," EPA/625/R-92/002, U.S. Environmental Protection Agency Office of Research and Development, Center for Environmental Research Information, Cinn $\mathrm{OH}, \mathrm{pp}$. 3-9, 3-10 (1992).

4 Wicks, G.G., Schulz, R.L. and Clark, D.E., "Microwave Technology for Waste Management Applications Including Disposition of Electronic Circuitry," presented at the 100th Annual Meeting of the American Ceramic Society, Cinn. OH, May 3-6, 1998, to be published in the proceedings.

5 Wicks, G.G., Clark, D.E., and Schulz, R.L., "Hybrid Microwave Technology for Waste Management Applications," presented at the 1998 American Institute of Chemical Engineers, New Orleans, LA, March 8-12, 1998.

6 Wicks, G.G., Clark, D.E., and Schulz, R.L., "Hybrid Microwave Technology for Waste Management Uses," presented at the 1997 American Chemical Society Meeting, Symposium on Microwave Energy Applied to Organic Synthesis and Environmental Remediation, Roanoke, VA, Oct. 19-22, 1997.

7 Wicks, G.G., Clark, D.E., Schulz, R.L. and Roboski, R.A., "Hybrid Microwave Technology for Treatment of Hazardous Wastes, Including Electronic Circuitry with Reclamation of Precious Metals," presented at the 1997 Global Demilitarization Symposium \& Exhibition, Reno, May 5-8, 1997.

8 Wicks, G.G., Clark, D.E., and Schulz, R.L., "Microwave Technology for Waste Management Applications: Treatment of Discarded Electronic Circuitry," presented at the First World Congress on Microwave Processing, Lake Buena Vista, FL, Jan. 5-9, 1997 and published in Microwaves Theory and Applications in Materials Processing IV, D.E. Clark, W.H. Sutton and D.A. Lewis, eds., Vol. 80, pp. 627- 637 (1997).

9 Schulz, R.L., Folz, D.C., Clark, D.E., Schmidt, C.J. and Wicks, G.G., "Microwave Waste Treatment System," presented at the First World Congress on Microwave Processing, Lake Buena Vista, FL, Jan. 5-9, 1997. 
10 Schulz, R.L., Folz, D.C., Clark, D.E., Schmidt, C.J. and Wicks, G.G., "Microwave Treatment of Emissions from Waste Materials," Microwave Processing of Materials V, M.F. Iskander, J.O. Kiggans,Jr., C. Bolomey, eds., Materials Research Society Symposium Proceedings, Vol. 430, pp. 549-554 (1996).

11 Wicks, G.G., Clark, D.E., Schulz, R.L. and Folz, D.C., "Microwave Technology for Waste Management Applications Including Disposition of Electronic Circuitry," Microwaves: Theory \& Application in Materials Processing III, Ceramic Transactions, D.E. Clark, D.C. Folz, S.J. Oda and R. Silberglitt, eds., Vol. 59, pp. 79-89 (1995).

12 Schulz, R.L., Folz, D.C., Clark, D.E., Schmidt, C.J. and Wicks, G.G., "Microwave Treatment of Emissions from the Destruction of Electronic Circuitry," Microwaves: Theory \& Application in Materials Processing III, Ceramic Transactions, D.E. Clark, D.C. Folz, S.J. Oda and R. Silberglitt, eds., Vol. 59, pp. 107-114 (1995).

13 Schulz, R.L., Folz, D.C., Clark, D.E., and Wicks, G.G., "Microwave Energy for Waste Remediation Applications," Microwave Processing of Materials IV, M.F. Iskander, R.J. Lauf, W.H. Sutton, eds., Materials Research Society Symposium Proceedings, Vol. 347, pp. 401-406 (1994).

14 Schulz, R.L., Folz, D.C., Clark, D.E., Wicks G.G., and Hutcheon, R.M., "Applications of Microwave Energy for Waste Remediation," in Proceedings of the 28th Microwave Power Symposium of the International Microwave Power Institute Symposium, Montreal, Quebec, pp. 9-18 (1993).

15 Schulz, R.L., Folz, D.C., Clark, D.E., and Wicks, G.G., "Microwave Destruction/ Vitrification of Electronic Components," Ceramic Transactions, Microwaves: Theory and Application in Materials Processing II D.E. Clark, W.R. Tinga and J.R. Laia, eds., Vol. 36, pp. 81- 88 (1993).

16 Schulz, R.L., Folz, D.C., Clark, D.E., Hutcheon, R.M. and Wicks, G.G., "Microwave Processing of Simulated Nuclear Waste Glass II," Ceramic Transactions, Microwaves: Theory and Application in Materials Processing II, D.E. Clark, W.R. Tinga and J.R. Laia, eds., Vol. 36, pp. 89-97 (1993).

17 Schulz, R.L., Fathi, Z., Clark, D.E., and Wicks G.G., "Microwave Processing Simulated Nuclear Waste Glass," presented at the Symposium on Microwaves: Theory and Application in Materials Processing, April 28- May 2, 1991, Cinn. OH, and published in Ceramic Transactions, Nuclear Waste Management IV, G.G. Wicks, D.F. Bickford and L.R. Bunnell, eds., Vol. 23, pp. 779-786 (1991).

18 Wicks, G.G. and Schulz, R.L., "Proposal for a "Hot" TRU Microwave Demonstration Project Hybrid Microwave Treatment of SRS TRU \& Mixed Wastes (U)," WSRC-TR-99-00178, May 17, 1999, Westinghouse Savannah River Company, Aiken, SC (1999). 